\title{
Kinetic and Equilibrium Studies for Dual Functional Adsorbent with Amino Group Magnetite
}

\author{
Chyow-San Chiou' ${ }^{1}$ and Hua-Wei Chen ${ }^{2 *}$
}

${ }^{1}$ Department of Environmental Engineering, Nationall-LanUniversity, I-Lan, Taiwan, China

${ }^{2}$ Department of Cosmetic Application and Management, St. Mary's Junior College of Medicine, Nursing and Management, Yi-Lan, Taiwan, China

\begin{abstract}
A dual functional adsorbent (EDA/MMA/OA/ $\mathrm{Fe}_{3} \mathrm{O}_{4}$ ) with amino group magnetite has been synthesized to behave as an anionic or cationic adsorbent (for the adsorption of phosphate or copper) by adjusting the $\mathrm{pH}$ value to make amino group protonic or neutral. The adsorptions of phosphate and copper ions by the dual functional adsorbent were investigated using kinetic, equilibrium, thermodynamic, and surface characteristic experiments. The adsorption behaviors for both copper ions and phosphate by EDA/MMA/OA/Fe $\mathrm{O}_{4}$ were in good agreement with the Langmuir adsorption isotherm with the maximum adsorption capacities of 7.096 for the copper ion and $34.5071 \mathrm{mg} \mathrm{g}^{-1}$ for phosphate, respectively. The optimum conditions for the desorption of copper ions and phosphate were $0.1 \mathrm{M} \mathrm{HNO}_{3}$ and $0.05 \mathrm{M} \mathrm{NaOH}$, respectively. After three cycles, the adsorption capacity of the recycled EDAMMA/OA/Fe ${ }_{3} \mathrm{O}_{4}$ for copper ions and phosphate exhibited a loss of about $17.1 \%$ and $28.1 \%$, respectively.
\end{abstract}

Keywords: Adsorb; Copper ions; Magnetic; Adsorbent; Phosphate

\section{Introduction}

Pharmaceuticals and personal care products (PPCPs) are a class of emerging contaminants which include commonly used medicinal, cosmetic and personal hygiene products [1]. Great concern has been raised about PPCPs due to their potential adverse impacts on ecological safety and human health [2]. Among the contaminants of PPCPs, cosmetic wastewater is the main contributor due to its large quantities. The main components of wastewater from a cosmetic manufacturing facility before further treatments include the surfactants, heavy metals, cations, and anions [3]. In this study, trace concentrations of copper and total concentrations of phosphorous were $16.8 \mu \mathrm{g} \mathrm{L}^{-1}$ and $4.89 \mathrm{mg}$ $\mathrm{PL}^{-1}$, respectively.

Removing copper ions from wastewater is an important treatment procedure as copper is a highly toxic heavy metal since it causes stomach and intestinal distress, liver and kidney damage, and anemia $[4,5]$. Traditional metal ion treatment processes include chemical precipitation, ion exchange, electrolysis, reverse osmosis, adsorption, etc. $[5,6]$. Besides, excess phosphate in rivers can lead to significant eutrophication and water quality problems, including harmful algal blooms, as well as depletion of dissolved oxygen, which subsequently results in the decline of aquatic life [7]. In order to reduce or reuse the amount of phosphate in water, several techniques have been developed to remove phosphate from aqueous media, such as chemical precipitation, biological treatment, and adsorption [8,9]. Among these treatment methods, adsorption has been considered one of the most suitable and effective methods for the removal of both copper ions and phosphate [9-11].

The application of magnetic adsorbent technology to solve environmental problems has received considerable attention in recent years. Magnetic adsorbents (various magnetic particles, $\mathrm{Fe}_{2} \mathrm{O}_{3}$ and $\mathrm{Fe}_{3} \mathrm{O}_{4}$ ) can be used to adsorb contaminants from aqueous or gaseous effluents [12,13]. After the adsorption is carried out, the adsorbent can be separated from the medium by a simple magnetic process $[14,15]$. These adsorbents have a variety of surface functional groups which can be tailored for use in specific applications. Poly (2-hydroxyethylmethacrylate), poly(oxy-2,6-dimethyl-1,4-phenylene), polyvinyl-butyral, and chitosan are typical adsorbents which are used in different applications [15-17].
The objective of this study was to investigate the removal of both phosphates and copper ions from aqueous solutions using amino group magnetite. Kinetic, equilibrium, and characteristic experiments were performed to characterize the phosphate and copper ions of the amino group magnetite. Sorption kinetic and equilibrium isotherm models were used for data analysis. This will open up a potential broad application in cosmetic wastewater treatment (Table 1).

\section{Materials and Methods}

\section{Adsorption and desorption}

In adsorption experiments, the adsorbent concentration was controlled at $0.5 \mathrm{~g}$ in a $50 \mathrm{~mL}$ solution, and the equilibrium time was considered as $24 \mathrm{~h}$ [18]. Effects of the $\mathrm{pH}$ (2.0-6.0), kinetic experiments (0 90 $\mathrm{min}$ ), adsorption isotherm (initial phosphate concentration $400 \sim 800 \mathrm{mg} \mathrm{L}^{-1}$ and initial copper ion concentration $50 \sim 150 \mathrm{mg} \mathrm{L}^{-1}$ ), and thermodynamic studies $(283 \sim 313 \mathrm{~K})$ on adsorption were studied. The $\mathrm{pH}$ value of the solution was controlled by adding $0.1 \mathrm{~N} \mathrm{HNO}_{3} /$ $\mathrm{NaOH}$.

Desorption experiments were carried out with $\mathrm{HNO}_{3} / \mathrm{HCl}$ solutions

\begin{tabular}{|c|c|c|c|c|c|}
\hline \multirow{2}{*}{$\begin{array}{c}\text { Magnetic } \\
\text { catalyst }\end{array}$} & \multirow{2}{*}{$\begin{array}{c}\text { Surface area } \\
\qquad\left(\mathrm{m}^{2} \mathbf{g}^{-1}\right)\end{array}$} & \multirow{2}{*}{ Treatments } & \multicolumn{3}{|c|}{ Adsorption (mg g $\left.{ }^{-1}\right)$} \\
\hline & & & $1^{\text {st }}$ cycle & $2^{\text {nd }}$ cycle & $3^{\text {rd }}$ cycle \\
\hline \multirow{2}{*}{$\begin{array}{c}\mathrm{EDA} / \mathrm{MMA} / \mathrm{OA} / \\
\mathrm{Fe}_{3} \mathrm{O}_{4}\end{array}$} & \multirow{2}{*}{34.99} & Phosphate & 11.71 & 9.70 & 8.42 \\
\hline & & Copper ion & 5.97 & 5.23 & 4.95 \\
\hline $\mathrm{Fe}_{3} \mathrm{O}_{4}$ & 18.06 & - & - & - & - \\
\hline
\end{tabular}

Table 1: The Brunauer-Emmett-Teller surface area and reuse performance of $\mathrm{Fe}_{3} \mathrm{O}_{4}$ and $\mathrm{EDA} / \mathrm{MMA} / \mathrm{OA} / \mathrm{Fe}_{3} \mathrm{O}_{4}$.

*Corresponding author: Chen HW, Department of Cosmetic Application and Management, St. Mary's Junior College of Medicine, Nursing and Management, Yi-Lan, Taiwan, China, Tel: +886939910932; E-mail: superlemi@smc.edu.tw

Received February 16, 2016; Accepted August 08, 2016; Published August 15, 2016

Citation: Chiou CS, Chen HW (2016) Kinetic and Equilibrium Studies for Dual Functional Adsorbent with Amino Group Magnetite. Int J Waste Resour 6: 242. doi: 10.4172/2252-5211.1000242

Copyright: $\odot 2016$ Chiou CS, et al. This is an open-access article distributed under the terms of the Creative Commons Attribution License, which permits unrestricted use, distribution, and reproduction in any medium, provided the original author and source are credited. 
in the concentration range of $0.001 \sim 1 \mathrm{M}$. A $0.5 \mathrm{~g}$ amount of the EDA/ $\mathrm{MMA} / \mathrm{OA} / \mathrm{Fe}_{3} \mathrm{O}_{4}$ adsorbent adsorbed with copper ion/phosphate was placed into $50 \mathrm{~mL}$ of an $\mathrm{HNO}_{3} / \mathrm{HCl}$ solution with thermostatic shaking for a time period of up to $24 \mathrm{~h}$. The desorption efficiency (DE) was determined from the following equation (Equation (1)):

$$
D E=\frac{C \times V}{q \times m} \times 100 \%
$$

where $\mathrm{C}\left(\mathrm{mg} \mathrm{L}^{-1}\right)$ is the concentration of copper ions or phosphate in the desorption solution, $\mathrm{V}$ is the volume of the desorption solution, $\mathrm{q}\left(\mathrm{mg} \mathrm{g}^{-1}\right)$ is the amount of copper ion/phosphate adsorbed on the adsorbents before the desorption experiment, and $\mathrm{m}(\mathrm{g})$ is the amount of the adsorbent used in the desorption experiments.

\section{Synthesis and instruments}

The preparation methods of the dual functional adsorbent (EDA/ $\mathrm{MMA} / \mathrm{OA} / \mathrm{Fe}_{3} \mathrm{O}_{4}$ ) follow up our previously study [19]. The magnetic polymer particles (MMA/OA/ $\mathrm{Fe}_{3} \mathrm{O}_{4}$ ) were prepared by using methyl methacrylate (MMA) as the functional monomer, ethylene glycol dimethacrylate (EDGMA) as the cross-linking agent, polyvinyl pyrrolidone (PVP) as the stabilizer, 2,2-azodiisobutyronitrile (AIBN) as the radical initiator and ethanol as the solvent. As shown in Figure 1,
MMA/OA/ $\mathrm{Fe}_{3} \mathrm{O}_{4}$ modified with amino group (EDA/MMA/OA/ $/ \mathrm{Fe}_{3} \mathrm{O}_{4}$ ) was prepared by using ethylenediamine (EDA) and acetonitrile as a solvent and separated by an external magnetic field.

The concentrations of copper ions were determined by standard spectrophotometric methods using a polarized Zeeman atomic absorption spectrophotometer (Z-2000, Hitachi, Japan). The concentration of phosphate was determined using standard methods [20] using a spectrophotometer (Lambda 25, Perkin Elmer, USA).

\section{Results and Discussion}

\section{Point of zero charge (PZC) analysis}

PZC analysis can estimate the adsorption behavior of materials at a certain $\mathrm{pH}$ and provide reliable evidence of the mechanism of adsorption of copper ion or phosphate onto the adsorbent. As can be seen in Figure 2, the $\mathrm{PZC}$ results for $\mathrm{Fe}_{3} \mathrm{O}_{4}, \mathrm{SiO}_{2} / \mathrm{Fe}_{3} \mathrm{O}_{4}, \mathrm{MMA} / \mathrm{OA} / \mathrm{Fe}_{3} \mathrm{O}_{4}$ and $\mathrm{EDA} / \mathrm{MMA} / \mathrm{OA} / \mathrm{Fe}_{3} \mathrm{O}_{4}$ were 7.0, 6.2, 6.0 and 8.1, respectively, and these results were similar to results [21].

\section{Effect of $\mathrm{p}^{\mathrm{H}}$ on adsorption of copper ion and phosphate ion}

The performance of the EDA/MMA/OA/ $/ \mathrm{Fe}_{3} \mathrm{O}_{4}$ adsorbent in
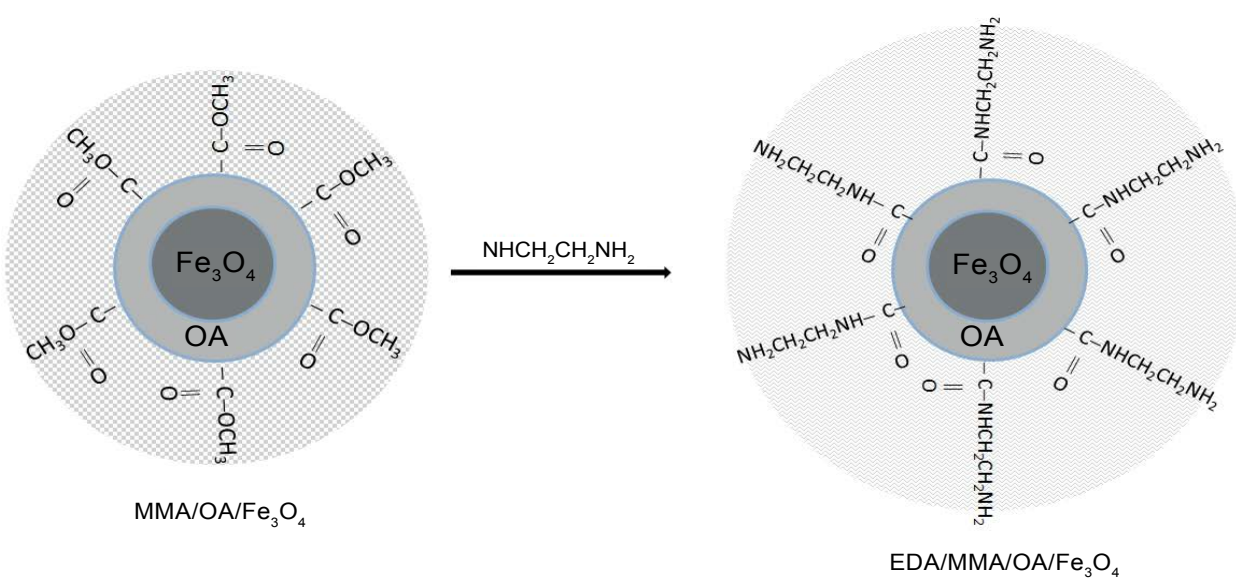

Figure 1: Preparation and molecule structure of EDA/MMA/OA/Fe $\mathrm{O}_{4}$.

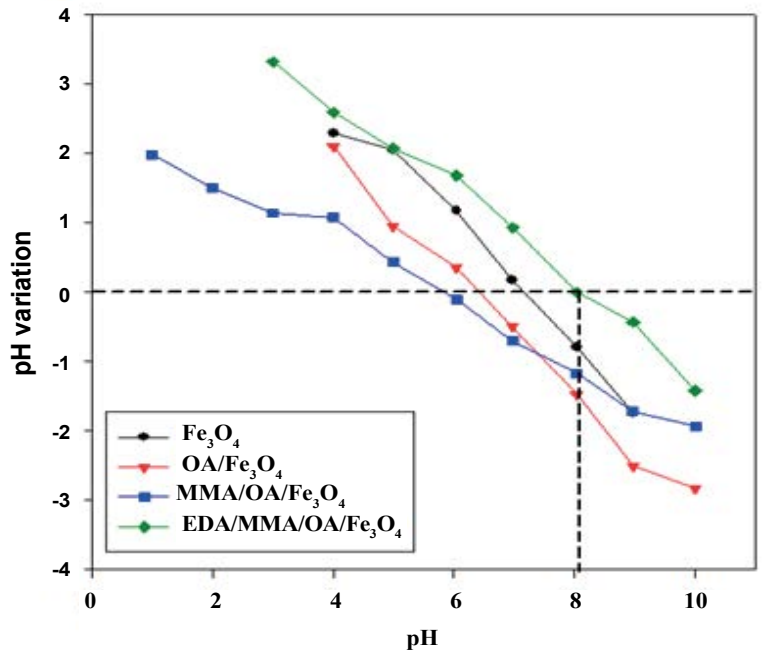

Figure 2: Effect of $\mathrm{pH}$ values on zeta potential of $\mathrm{Fe}_{3} \mathrm{O}_{4}, \mathrm{SiO}_{2} / \mathrm{Fe}_{3} \mathrm{O}_{4}, \mathrm{MMA} / \mathrm{OA} / \mathrm{Fe}_{3} \mathrm{O}_{4}$ and EDA/MMA/OA/Fe $\mathrm{O}_{4}$ 
adsorbing copper and phosphate ions in solutions with different $\mathrm{p}^{\mathrm{H}}$ values is shown in Fig. 3. Experimental conditions included initial concentrations of copper ion $=100 \mathrm{mg} \mathrm{L}^{-1}$ and phosphate ion $=500$ $\mathrm{mg} \mathrm{L}{ }^{-1}, \mathrm{EDA} / \mathrm{MMA} / \mathrm{OA} / \mathrm{Fe}_{3} \mathrm{O}_{4}=10 \mathrm{~g} \mathrm{~L}^{-1}$, reaction time $=24 \mathrm{~h}$, and temperature $(\mathrm{T})=298 \mathrm{~K}$. The results revealed that the adsorption behavior of $\mathrm{EDA} / \mathrm{MMA} / \mathrm{OA} / \mathrm{Fe}_{3} \mathrm{O}_{4}$ with copper ions and phosphate ions is strongly $\mathrm{pH}$-dependent.

The amino groups $\left(-\mathrm{NH}_{2}\right)$ of EDA/MMA/OA/ $/ \mathrm{Fe}_{3} \mathrm{O}_{4}$ are or are not protonated $\left(\mathrm{NH}_{3+}\right)$, depending on the $\mathrm{pH}$ values of the solution. The amine forms of $\mathrm{NH}_{3}^{+}$and $\mathrm{NH}_{2}$ will attract anions [22] and cations [23], respectively. In a solution with $\mathrm{pH} 3$, the adsorption efficiency of $\mathrm{Cu}^{2+}$ by EDA/MMA/OA/Fe3O4 was nearly zero, but for phosphate ions it was relatively higher $(22.1 \%)$. In solutions with low $\mathrm{pH}$ values, a relatively high concentration of protons would strongly compete with the copper ions for amine sites, so that the adsorption of copper ions was significantly decreased.

Furthermore, the protonation of the amino groups led to strong electrostatic repulsion of the copper ions to be adsorbed. As a result, it became difficult for the copper ions to come into close contact with the adsorbent surface and be adsorbed onto it; this resulted in poor adsorption performance for copper ions in a solution with $\mathrm{pH} \leq 3$. On the other hand, the protonated amines possess a strong electrostatic attraction to phosphate ions, which leads to a high adsorption capacity. Thus, the phosphate ion adsorption increased with the decrease in $\mathrm{p}^{\mathrm{H}}$ value because the dominant phosphate forms in the solution are $\mathrm{H}_{3} \mathrm{PO}_{4}$ and $\mathrm{H}_{2} \mathrm{PO}_{4}$. The solution's $\mathrm{pH}$ value determines whether the amino groups on the synthetic magnetic adsorbent are protonated [24]. Protonated amino groups can adsorb phosphate anions. Lower solution $\mathrm{p}^{\mathrm{H}}$ values make EDA/MMA/OA/ $\mathrm{Fe}_{3} \mathrm{O}_{4}$ more protonated, thus, attracting more phosphate anions.

As a result, the optimum $\mathrm{p}^{\mathrm{H}}$ values for phosphate ion adsorption were found to be in the $\mathrm{pH}$ range from 2 to 3 , and all further adsorption experiments were carried out with a solution $\mathrm{p}^{\mathrm{H}}$ of 3 for $\mathrm{PO}_{43-}$ due to the consideration of actual engineering application and the overdose of acid.

At higher solution $\mathrm{p}^{\mathrm{H}}$ values from 4 to 6 (lower proton concentrations), regarding copper ions, the competition between protons and copper ions for the amino groups became less significant, and more of the amino groups existed in their neutral form, which reduced the electrostatic repulsion of the copper ions. Furthermore, the unpaired electrons of the amino groups could create coordinate bonds with the copper ions. More copper ions could thus be adsorbed onto the surfaces of EDA/MMA/OA/ $\mathrm{Fe}_{3} \mathrm{O}_{4}$, resulting in an observed increase in $\mathrm{Cu}^{2+}$ adsorption on the adsorbent. With regard to phosphate ions, in solutions with a higher $\mathrm{p}^{\mathrm{H}}$, fewer protons are available to protonate the amino groups $\left(-\mathrm{NH}_{2}\right)$ of $\mathrm{EDA} / \mathrm{MMA} / \mathrm{OA} / \mathrm{Fe}_{3} \mathrm{O}_{4}$ to form $\mathrm{NH}_{3}{ }^{+}$, thereby decreasing the electrostatic attractions between negatively charged anions; this decrease is attributed to the lower degree of adsorption.

There was a complete removal of copper ions from the solution when the solution's $\mathrm{p}^{\mathrm{H}}$ value exceeded 6.5. This took place because copper ions began to precipitate as $\mathrm{Cu}(\mathrm{OH})_{2}$. Therefore, copper ions were removed by both adsorption and precipitation when the solution's
$\mathrm{pH}$ value exceeded 6.5 [25]. As a result, the optimum $\mathrm{pH}$ values for $\mathrm{Cu}_{2+}$ adsorption were found to be in the $\mathrm{p}^{\mathrm{H}}$ range from 5 to 6 , and all further adsorption experiments were carried out in solutions with a $\mathrm{p}^{\mathrm{H}}$ of 5.5 for $\mathrm{Cu}^{2+}$.

\section{Adsorption isotherms of copper ions and phosphate ions}

The data equilibrium isotherms of adsorption were conducted in $298 \mathrm{~K}$, five initial concentrations of copper ions with the solutions' $\mathrm{p}^{\mathrm{H}}$ $5.5\left(50,75,100,125\right.$, and $\left.150 \mathrm{mg} \mathrm{L}^{-1}\right)$, and those of phosphate ions with the solutions' $\mathrm{p}^{\mathrm{H}} 3.0\left(400,500,600,700\right.$, and $\left.800 \mathrm{mg} \mathrm{L}^{-1}\right)$. The Langmuir and Freundlich equations $[26,27]$ were applied to experimental data to examine the relationship between sorption ion concentration at equilibrium. The Langmuir equation could be expressed as follows (Equation (2)):

$$
\frac{1}{\mathrm{Q}_{e}}=\frac{1}{Q_{m}}+\frac{1}{Q_{m} k_{L}} \frac{1}{C_{e}}
$$

where Qe and Qm are the equilibrium and maximum adsorption capacities of copper ion/phosphate on the adsorbent $\left(\mathrm{mg} \mathrm{g}^{-1}\right)$, Ce, the equilibrium concentration of copper ion/phosphate in solution (mg L $\mathrm{L}^{-1}$ ), and $\mathrm{kL}$, the Langmuir adsorption constant $\left(\mathrm{L} \mathrm{mg}^{-1}\right)$. The linear form of the Freundlich equation can be represented as follows (Equation (3)):

$$
\log Q_{\mathrm{e}}=\log k_{\mathrm{F}}+\frac{1}{n} \log C_{\mathrm{e}}
$$

where $\mathrm{kF}$ is the Freundlich constant $\left(\mathrm{L} \mathrm{mg}^{-1}\right)$, and $\mathrm{n}$ is the heterogeneity factor. The values of $\mathrm{qm}$ and $\mathrm{kL}$ are determined from the slope and intercept of the linear plots of Ce/Qe versus Ce, and the values of $\mathrm{kF}$ and $1 / \mathrm{n}$ are determined from the slope and intercept of the linear plot of $\operatorname{lnQ}$ e versus $\ln C$ e, as shown in Table 2 . The correlation coefficient of the Langmuir isotherms was found to be 0.9999 for the copper ions and 0.9918 for phosphate. However, those of the Freundlich isotherms for copper and phosphate ions were 0.9844 and 0.9872 , respectively. Obviously, the data were fitted better by the Langmuir equation than by the Freundlich equation for both copper and phosphate. Furthermore, fitting of the Langmuir isotherm indicates a monolayer coverage for both $\mathrm{Cu}^{2+}$ and phosphate on the EDA/MMA/OA/ $\mathrm{Fe}_{3} \mathrm{O}_{4}$ surface during adsorption. Moreover, the maximum monolayer phosphate uptake of $34.507 \mathrm{mg} \mathrm{g}^{-1}$ was significantly higher than the maximum monolayer copper uptake of $7.096 \mathrm{mg} \mathrm{g}^{-1}$ (Figure 3).

\section{Adsorption kinetics}

The effects of a contact time on the adsorption of $\mathrm{Cu}^{2+}$ and phosphate by EDA/MMA/OA/ $/ \mathrm{Fe}_{3} \mathrm{O}_{4}$ at various temperatures $(10,25$, and $40^{\circ} \mathrm{C}$ ) were also evaluated, as shown in Table 3 . The adsorption kinetics were analyzed using the pseudo-first-order and pseudosecond-order kinetic models, expressed in their linearized forms as Equation (4) and (5), respectively [28]:

$$
\begin{aligned}
& \log \left(q_{e}-q_{t}\right)=\log q_{e}-\frac{k_{1}}{2.303} t \\
& \frac{t}{q_{t}}=\frac{1}{k_{2} q_{e}^{2}}+\frac{1}{q_{e}} t
\end{aligned}
$$

\begin{tabular}{|c|c|c|c|c|c|}
\hline \multirow{2}{*}{ Treatments } & \multicolumn{3}{|c|}{ Langmuir } & \multicolumn{2}{|c|}{ Freundlich } \\
\cline { 2 - 5 } & $\mathbf{Q}_{\mathbf{m}}\left(\mathbf{m g ~ g}^{-1}\right)$ & $\boldsymbol{K}_{\mathbf{L}}\left(\mathbf{L} \mathbf{m g}^{-1}\right)$ & $\mathbf{R}^{\mathbf{1}}$ & $\mathbf{K}_{\boldsymbol{F}}$ & 2.2393 \\
\hline Phosphate-ion & 34.507 & 0.0044 & 0.9918 & 2.6371 & 0.9872 \\
\hline Copper ion & 7.096 & 0.0245 & 0.9999 & 1.728 & 0.668 \\
\hline
\end{tabular}

Table 2: Parameter values of different types of adsorption isotherm models fitting the experimental results for copper ions and phosphate adsorption, respectively on the $\mathrm{EDA} / \mathrm{MMA} / \mathrm{OA} / \mathrm{Fe}_{3} \mathrm{O}_{4}$ adsorbents. 


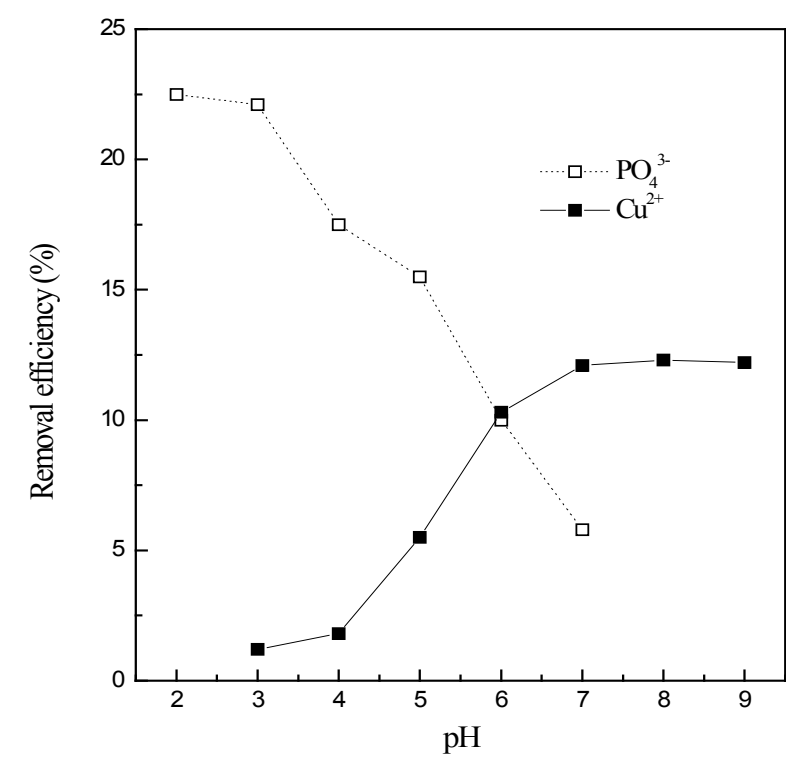

Figure 3: Effect of solution's pH values on copper ion adsorption on the EDA/ $\mathrm{MMA} / \mathrm{OA} / \mathrm{Fe}_{3} \mathrm{O}_{4}$ adsorbent.

\begin{tabular}{|c|c|c|c|c|c|}
\hline \multirow{2}{*}{ Treatments } & \multirow{2}{*}{ Temperature } & \multicolumn{2}{|c|}{$\mathbf{R}^{2}$} & \multirow{2}{*}{$\begin{array}{l}\text { Rate Constants } \\
k_{2}\left(\mathrm{~g} \mathrm{mg}^{-1} \mathrm{~min}^{-1}\right)\end{array}$} & \multirow{2}{*}{$\begin{array}{c}\begin{array}{c}\text { Activated } \\
\text { Energy }\end{array} \\
\mathrm{Ea}\left(\mathrm{kJ} \mathrm{mole}^{-1}\right)\end{array}$} \\
\hline & & $1^{\text {st }}$ order & $2^{\text {nd }}$ order & & \\
\hline \multirow{3}{*}{$\begin{array}{l}\text { Phosphate- } \\
\text { ion }\end{array}$} & $10^{\circ} \mathrm{C}$ & 0.062 & 0.997 & 0.093 & \multirow{3}{*}{7.344} \\
\hline & $25^{\circ} \mathrm{C}$ & 0.096 & 0.999 & 0.107 & \\
\hline & $40^{\circ} \mathrm{C}$ & 0.186 & 0.999 & 0.125 & \\
\hline \multirow{3}{*}{ Copper ion } & $10^{\circ} \mathrm{C}$ & 0.784 & 0.998 & 0.2214 & \multirow{3}{*}{13.356} \\
\hline & $25^{\circ} \mathrm{C}$ & 0.754 & 0.999 & 0.2981 & \\
\hline & $40^{\circ} \mathrm{C}$ & 0.757 & 0.999 & 0.3804 & \\
\hline
\end{tabular}

Table 3: Parameter values of the kinetics models fitting the experimental results for copper ions and phosphate adsorption on the EDA/MMA/OA/Fe $\mathrm{O}_{4}$ adsorbent.

where, $\mathrm{qt}\left(\mathrm{mg} \mathrm{g}^{-1}\right)$ is the adsorption uptake at time $\mathrm{t}(\mathrm{min})$; qe ( $\mathrm{mg}$ $\left.\mathrm{g}^{-1}\right)$ is the adsorption capacity at adsorption equilibrium; and $\mathrm{k} 1\left(\mathrm{~min}^{-1}\right)$ and $\mathrm{k} 2\left(\mathrm{~g}(\mathrm{mg} \bullet \mathrm{min})^{-1}\right)$ are the kinetics rate constants for the pseudofirst-order and the pseudo-second-order models, respectively. The results distinctly revealed that the adsorption kinetics for copper ions and phosphate closely follow the pseudo-second-order kinetic model rather than the pseudo-first-order kinetic model, which suggested that the adsorption process was quite rapid and was probably dominated by a chemical adsorption phenomenon.

Moreover, the temperature dependence of the kinetic parameter $\mathrm{k} 2$ could be described by the Arrhenius equation (Equation (6)):

$$
\ln k=\ln A-E_{a} / R T
$$

where $\mathrm{A}, \mathrm{Ea}, \mathrm{T}$ and $\mathrm{R}$ are the frequency factor, activation energy, temperature $(\mathrm{K})$, and gas constant, respectively. By plotting lnk2 against $1 / \mathrm{T}(\mathrm{K}-1)$, the determined $\mathrm{Ea}$ of the copper ion and phosphate were $13.356 \mathrm{~kJ} \mathrm{~mol}^{-1}$ and $7.344 \mathrm{~kJ} \mathrm{~mol}^{-1}$, respectively.

\section{Desorption}

$\mathrm{HNO} 3$ and $\mathrm{NaOH}$ solutions with different concentrations at the loading of EDA/MMA/OA/ $\mathrm{Fe}_{3} \mathrm{O}_{4}=5 \mathrm{~g} \mathrm{~L}^{-1}$, reaction time $=24 \mathrm{~h}$, and $\mathrm{T}=298 \mathrm{~K}$ were examined in a desorption study, as listed in Table 4 . It is interesting to note that the maximum desorption efficiency of copper ions was achieved at a concentration of $0.1 \mathrm{M} \mathrm{HNO}_{3}$, and any higher or lower HNO3 concentrations resulted in lower desorption efficiencies. Thus, one may assume that the reactions taking place in acidic desorption solutions can be given by the following equations [29]:

$$
\begin{aligned}
& \mathrm{Cu}^{2+} \ldots \mathrm{NH}_{2}-\mathrm{MMA} / \mathrm{OA} / \mathrm{Fe}_{3} \mathrm{O}_{4}+\mathrm{H}^{+} \Leftrightarrow \mathrm{NH}_{3}^{+}-\mathrm{MMA} / \mathrm{OA} / \mathrm{Fe}_{3} \mathrm{O}_{4}+\mathrm{Cu}^{2+} \\
& \mathrm{NH}_{2}-\mathrm{MMA} / \mathrm{OA} / \mathrm{Fe}_{3} \mathrm{O}_{4}+\mathrm{H}^{+} \Leftrightarrow \mathrm{NH}_{3}^{+}-\mathrm{MMA} / \mathrm{OA} / \mathrm{Fe}_{3} \mathrm{O}_{4}
\end{aligned}
$$

At an $\mathrm{HNO}_{3}$ concentration $>0.1 \mathrm{M}$ in an aqueous solution, the high concentration of $\mathrm{H}+$ will shift both Equation (7) and (8) toward the right-hand side and more MMA/OA/ $\mathrm{Fe}_{3} \mathrm{O}_{4} \mathrm{NH}_{3}{ }^{+}$will be generated. However, the generation of $\mathrm{MMA} / \mathrm{OA} / \mathrm{Fe}_{3} \mathrm{O}_{4}-\mathrm{NH}_{3}{ }^{+}$will favor the reverse reaction of Equation (7) to the left-hand side and simultaneously hinder the desorption of copper ions from the adsorbent. Therefore, when the concentration of $\mathrm{HNO}_{3}$ in the desorption solution exceeded $0.1 \mathrm{M}$, the results revealed that the desorption efficiency was reduced. On the other hand, at an $\mathrm{HNO}_{3}$ concentration $<0.1 \mathrm{M}$ in an aqueous solution, the low concentration of $\mathrm{H}^{+}$may be insufficient to drive the reaction in Equation (7) to the right-hand side for the desorption of copper ions. Therefore, the results observed show that the desorption efficiencies were lower than those at a $0.1 \mathrm{M} \mathrm{HNO}_{3}$ concentration.

The results of the phosphate ion desorption is also interesting to note since maximum desorption efficiency was achieved at an $\mathrm{NaOH}$ concentration greater than $0.05 \mathrm{M}$ and the desorption efficiencies were lower at lower $\mathrm{NaOH}$ concentrations. The reason for this is similar to the former explanation of $\mathrm{Cu}_{2+}$ desorption from a magnetic adsorbent. In order to explain this trend, one may assume that the reactions taking place in basic desorption solutions are represented by the following equations:

$$
\begin{aligned}
& \mathrm{PO}_{4}^{3-} \cdots \mathrm{NH}_{3}^{+}-\mathrm{MMA} / \mathrm{OA} / \mathrm{Fe}_{3} \mathrm{O}_{4}+\mathrm{OH}^{-} \Leftrightarrow \mathrm{NH}_{2}-\mathrm{MMA} / \mathrm{OA} / \mathrm{Fe}_{3} \mathrm{O}_{4}+\mathrm{PO}_{4}^{3-}+\mathrm{H}_{2} \mathrm{O} \\
& \mathrm{NH}_{2}^{-}-\mathrm{MMA} / \mathrm{OA} / \mathrm{Fe}_{3} \mathrm{O}_{4}+\mathrm{OH}^{-} \Leftrightarrow \mathrm{NH}^{-}-\mathrm{MMA} / \mathrm{OA} / \mathrm{Fe}_{3} \mathrm{O}_{4}+\mathrm{H}_{2} \mathrm{O}
\end{aligned}
$$

The added will shift the balance in both Equation 9 and 10 toward the right-hand side and a higher amount of MMA/OA/ $/ \mathrm{Fe}_{3} \mathrm{O}_{4} \mathrm{NH}$ - will be generated. Furthermore, the generation of MMA/OA/ $\mathrm{Fe}_{3} \mathrm{O}_{4} \mathrm{NH}$ - will facilitate phosphate desorption from the magnetic adsorbent. It was found that an $\mathrm{NaOH}$ concentration of $0.05 \mathrm{M}$ was sufficient to achieve desorption of the phosphate. Corresponding to the experimental results of adsorptions at various $\mathrm{p}^{\mathrm{H}}$ values, the EDA/MMA/OA/ $\mathrm{Fe}_{3} \mathrm{O}_{4}$ adsorbent did not significantly adsorb phosphate ions with the increasing $\mathrm{p}^{\mathrm{H}}$ value, which suggests that the adsorbed phosphate ion could possibly be desorbed in a solution with an increasing $\mathrm{p}^{\mathrm{H}}$ value.

\section{Conclusions}

A dual functional adsorbent (EDA/MMA/OA/ $\mathrm{Fe}_{3} \mathrm{O}_{4}$ ) was developed as a porous adsorbent for the adsorption of copper ions and phosphate. In a batch system, the optimal $\mathrm{p}^{\mathrm{H}}$ values for copper ions and phosphate adsorptions were 5.5 and 3 , respectively. The adsorption equilibrium data were better fitted by the Langmuir equation than by the Freundlich equation for both copper ions and phosphate. Moreover,

\begin{tabular}{|c|c|c|}
\hline $\begin{array}{c}\text { Concentration of } \\
\mathbf{H N O}_{3} \text { or } \mathbf{N a O H}(\mathbf{M})\end{array}$ & $\begin{array}{c}\text { Copper ion desorption } \\
\mathbf{( \% )}\end{array}$ & $\begin{array}{c}\text { Phosphate desorption } \\
\mathbf{( \% )}\end{array}$ \\
\hline 0.01 & 82.6 & 86.1 \\
\hline 0.05 & 85.2 & 90.7 \\
\hline 0.1 & 90.4 & 90.3 \\
\hline 0.5 & 84.1 & 89.5 \\
\hline 1.0 & 84.6 & 88.9 \\
\hline
\end{tabular}

Table 4: Desorption efficiency of copper ions and phosphates from the EDA $\mathrm{MMA} / \mathrm{OA} / \mathrm{Fe}_{3} \mathrm{O}_{4}$ adsorbent in solutions with different $\mathrm{HNO}_{3}$ (for $\mathrm{Cu}^{2+}$ )/ $\mathrm{NaOH}$ (for phosphate) concentrations. 
Citation: Chiou CS, Chen HW (2016) Kinetic and Equilibrium Studies for Dual Functional Adsorbent with Amino Group Magnetite. Int J Waste Resour 6: 242. doi: 10.4172/2252-5211.1000242

the maximum monolayer's phosphate uptake of $34.507 \mathrm{mg} \mathrm{g}^{-1}$ was significantly higher than the maximum monolayer's copper uptake of $7.096 \mathrm{mg} \mathrm{g}^{-1}$. The adsorption kinetics for copper ions and phosphate closely follow the pseudo-second-order kinetic model rather than the pseudo-first-order kinetic model. The derived activation energies of EDA/MMA/OA/ $/ \mathrm{Fe}_{3} \mathrm{O}_{4}$, with the adsorption reaction of copper ions and phosphate were $13.356 \mathrm{~kJ} \mathrm{~mol}^{-1}$ and $7.344 \mathrm{~kJ} \mathrm{~mol}^{-1}$, respectively. The optimum conditions to desorb cationic and anionic adsorbates from the dual functional adsorbents were $0.1 \mathrm{M} \mathrm{HNO}_{3}$ for the copper ions and $0.05 \mathrm{M} \mathrm{NaOH}$ for phosphate, respectively. As expected, the prepared amino group magnetite (EDA/MMA/OA/ $\mathrm{Fe}_{3} \mathrm{O}_{4}$ ) exhibited improved capacities for copper ions and especially phosphate, which opened a novel field to water treatment.

\section{Acknowledgement}

This research was supported in part by Grant MOST 104-2622-E-562-001CC3 from the Ministry of Science and Technology, Republic of China.

\section{References}

1. Sun $Q$, Lv M, Hu A, Yang $X(215)$ Seasonal variation in the occurrence and removal of pharmaceuticals and personal care products in a wastewater treatment plant in Xiamen. J Hazard Mater 277: 69-75.

2. Jobling S, Nolan M, Tyler CR, Brighty G, Sumpter JP (1998) Widespread sexual disruption in wild fish. Environ Sci Technol 32: 2498-2506.

3. Carbajo JB, Perdigón-Melón JA, Petre AL, Rosal R, Letón P, et al. (2015) Personal care product preservatives: risk assessment and mixture toxicities with an industrial wastewater. Water Res 72: 174-185.

4. Brooks RR (1997) Pollution through Trace Elements, Environmental Chemistry. Plenum Press, New York.

5. Aguado J, Arsuaga JM, Arencibia A, Lindo M, Gascon V (2009) Aqueous heavy metals removal by adsorption on amine-functionalized mesoporous silica. J Hazard Mater 163: 213-221.

6. Gado M, Zaki S (2016) Studies on Thorium Adsorption Characteristics upon Activated Titanium Hydroxide Prepared from Rosetta IImenite Concentrate. Int J Waste Resource 6: 194.

7. Neal C, Jarvie HP, Howarth SM, Whitehead PG, Williams RJ, et al. (2000) The water quality of the River Kennet: initial observations on a lowland chalk stream impacted by sewage inputs and phosphorus remediation. Sci Total Environ 251: 477-496.

8. Snyder MV, Um W (2014) Adsorption Mechanisms and Transport Behavio between Selenate and Selenite on Different Sorbents. Int J Waste Resource 4: 144

9. Liu CJ, Li YZ, Luan ZK, Zhang ZY, Jia ZP (2007) Adsorption removal of phosphate from aqueous solution by active red mud. J Environ Sci 19: 11661170.

10. Chen H, Zheng X, Chen Y, Li M, Liu K, et al. (2014) Influence of Copper Nanoparticles on the Physical-Chemical Properties of Activated Sludge. PLoS ONE 9: e92871.

11. Ekmekyapar F, Aslan A, Bayhan YK, Cakici A (2006) Influence of coppe nanoparticles on the physical-chemical properties of activated sludge. J Hazard Mater 137: 293-298.

12. Sayin S, Ozcan F, Yilmaz M (2013) Two novel calixarene functionalized iron oxide magnetite nanoparticles as a platform for magnetic separation in the liquid-liquid/solid-liquid extraction of oxyanions. Mater Sci Eng 33: 2433-2439.

13. Ambashta RD, Sillanpaa M (2010) Water purification using magnetic assistance: a review. J Hazard Mater 180: 38-49.
14. Liang HF, Wang ZC (2010) Adsorption of bovine serum albumin on functionalized silica-coated magnetic $\mathrm{MnFe}_{2} \mathrm{O}_{4}$ nanoparticles. Mater Chem Phys 128: 964-969.

15. Butterworth MD, Illum L, Davis SS (2001) Preparation of ultrafine silica- and PEG-coated magnetite particles. Colloid Surf A-Physicochem Eng Asp 179: 93-102.

16. Patkowski J, Myśliwiec D, Chibowski S (2014) Adsorption of polyethyleneimine (PEI) on hematite. Influence of magnetic field on adsorption of PEI on hematite. Mater Chem Phys 354: 451-461.

17. Phan NTS, Jones CW (2006) Highly accessible catalytic sites on recyclable organosilane-functionalized magnetic nanoparticles: An alternative to functionalized porous silica catalysts. J Mol Catal A: Chem 253: 123-131.

18. Liu CC, Wang MK, Chioua CS, Li YS, Yangc CY, et al. (2009) Biosorption of chromium, copper and zinc by wine-processing waste sludge: Single and multicomponent system study. J Hazard Mater 171: 386-392.

19. Chiou CS, Chuang KJ, Chen HW, Chen YC, Chang SH (2015) Magnetite modified with amine polymer to adsorb indium ions. Powder Technol 279: 247 253.

20. APHA, AWWA, WEF (1998) Standard methods for the examination of water and wastewater.

21. Faraji M, Yamini Y, Rezae M (2010) Magnetic nanoparticles: synthesis stabilization, functionalization, characterization, and applications. J Phys D 7 $1-37$.

22. Annadurai G, Ling LY, Lee JF (2008) Adsorption of reactive dye from an aqueous solution by chitosan: isotherm, kinetic and thermodynamic analysis. $J$ Hazard Mater 152: 337-346.

23. Banerjee SS, Chen DH (2007) Fast removal of copper ions by gum Arabic modified magnetic nano-adsorbent. J Hazard Mater 147: 792-799.

24. Yang $Y$, Zhao $Y Q$, Babatunde AO, Wang L, Ren $Y X$, et al. (2006) Characteristics and mechanisms of phosphate adsorption on dewatered alum sludge. Sep Purif Technol 51: 193-200.

25. Ko DCK, Porter JF, McKay G (2003) Mass transport model for the fixed bed sorption of metal ions on bone char. Ind Eng Chem Res 42: 3458-3469.

26. Wong YC, Szeto YS, Cheung WH, Mckay G (2003) Equilibrium studies for acid dye adsorption onto chitosan. Langmuir 19: 7888-7894

27. Ho YS, McKay G (1998) Kinetic models for the sorption of dye from aqueous solution by wood. Trans Inst Chem Eng 76B: 183-191.

28. Mellah A, Chegrouche S, Barkat M (2006) The removal of uranium (VI) from aqueous solutions onto activated carbon: Kinetic and thermodynamic investigations. J Colloid Interf Sci 296: 434-441.

29. Liu CK, Bai R, Hong L (2006) Diethylenetriamine-grafted poly (glycidy methacrylate) adsorbent for effective copper ion adsorption. J Colloid Interf Sci 303: $99-108$. 